\title{
WATER-SAVING IRRIGATION REGIMES FOR VEGETABLE CROP PRODUCTION UNDER CONDITIONS OF VOLGA-DON INTERFLUVE
}

\author{
A.D. Akhmedov, E.E. Dzhamaletdinova, A.E. Zasimov \\ Volgograd State Agricultural University \\ Universitetskiy pr., 26, Volgograd, 400002, Russian Federation
}

\begin{abstract}
Irrigation regimes and rates of mineral fertilizers for obtaining the expected yields of vegetable crops under conditions of light chestnut soils of the Volga-Don interfluve are considered in the study. We established that irrigation regimes and norms of mineral fertilizers proposed in our field study for table beet (Beta vulgaris) and carrot (Daucus carota) cultivation allow yielding in the range of $60 \ldots 80 \mathrm{t} / \mathrm{ha}$. Thus, for example, the maximum yield of table beet $84.1 \mathrm{t} / \mathrm{ha}$ was obtained in the variant with $80 \%$ pre-irrigation soil moisture and $\mathrm{N}_{230} \mathrm{P}_{180} \mathrm{~K}_{100}$ fertilizer at a variable depth of soil moistening $(0.3 \ldots 0.5 \mathrm{~m})$. Changes in fertilizer dose from $\mathrm{N}_{130} \mathrm{P}_{80} \mathrm{~K}_{20}$ to $\mathrm{N}_{230} \mathrm{P}_{180} \mathrm{~K}_{100}$ contributed to $63.7 \ldots 84.1 \mathrm{t} /$ ha yield increase, which is $10-20 \%$ higher compared to other variants. Change in soil moisture from $70-80-70$ to $80-80-80 \%$ of FMC in combination with fertilizer dose from $\mathrm{N}_{150} \mathrm{P}_{70} \mathrm{~K}_{180}$ to $\mathrm{N}_{210} \mathrm{P}_{100} \mathrm{~K}_{260}$ increased carrot yields from an average of 57.9 to $81.6 \mathrm{t} / \mathrm{ha}$. The highest yields $(81.6 \mathrm{t} / \mathrm{ha})$ were obtained when maintaining pre-irrigation soil moisture of $80-80-80 \%$ of $\mathrm{FMC}$ and applying $\mathrm{N}_{210} \mathrm{P}_{100} \mathrm{~K}_{260}$ fertilizer rate. In general, beet and carrot cultivation on light chestnut soils using drip irrigation is the most efficient. To maintain water regimes of the soil adopted by the experiment, a different irrigation frequency was required. When increasing humidity level from 70 to $90 \%$ FMC frequency of irrigation increases, and irrigation rate decreases. The total consumption of moisture in the experiments increased with an increase in moisture content - from $4,417 \mathrm{~m}^{3} / \mathrm{ha}$ in the variant with $70 \%$ of $\mathrm{FMC}$ to $5105 \mathrm{~m}^{3} / \mathrm{ha}$ in the variant with $90 \%$ of FMC. The largest total water consumption of table beet was noted in the variant with a differentiated depth of soil wetting and averaged 4,530-5,105 $\mathrm{m}^{3} / \mathrm{ha}$. The share of irrigation water in the total water consumption of plants increased from 73.3 to $75.7 \%$. Application of mineral fertilizers reduces water consumption of table beet. The smallest coefficient was obtained in the second irrigation regime variant, when humidity was maintained at $80 \%$ of FMC with different wetting depth. This situation was observed in all variants of irrigation regimes and fertilizer applications. This confirms that differentiating wetting depth according to table beet growth stage makes it possible to use irrigation water more economically at all rates mineral fertilizer application.
\end{abstract}

Keywords: drip irrigation of vegetable crops, irrigation regime of vegetable crops, yield of vegetable crops, table beet and carrot water consumption, pre-irrigation soil moisture

\section{INTRODUCTION}

Currently, when growing vegetables, optimization of irrigation regime as a factor of integral significance has the first importance. It determines productivity per hectare and yield quality, total costs, water and energy resources demand, and public health situation. So, irrigation regime, irrigation technique, mechanization and automation should be improved, and new, more productive methods of irrigation should be created in order to increase efficiency of irrigation reclamation. Hence, experience of advanced 
farms of the region and the data of research institutions show that proper farming practices and optimal irrigation regime result in high and stable yields of vegetable crops. It is well known, that irrigation water costs, soil properties and plant productivity change depending on the irrigation methods used. Therefore, drip irrigation is promising in vegetable crop growing $[1-5,6,7]$.

Cultivation of vegetable crops, in particular carrots and beetroot, on irrigated lands of the Volgograd region is important. Hence, we are conducting research, which purpose is to determine optimal combination of irrigation regime and fertilizer application in order to obtain carrot and table beet yields at the level of 60, 70, $80 \mathrm{t} / \mathrm{ha}$.

\section{MATERIALS AND METHODS}

The research was conducted during 2015-2017 on two plots of Gorodishchensky district of Volgograd region, located in the zone of unstable moistening according to the generally accepted recommendations of B.A. Dospekhov, V.N. Pleshakov, G.F. Nikitenko [8-10]. The soils are light chestnut heavy loam, slightly waterpermeable. Humus content in $0-0.5 \mathrm{~m}$ soil layer is $1.87 \ldots 2.02 \%$, soil density is $1.31 \mathrm{t} / \mathrm{m}^{3}$, field moisture capacity (FMC) of dry soil is $22.93 \%$. Soils of the experimental plots have $7.0 \ldots 8.3 \mathrm{pH}$ and are not saline.

The content of available forms of nitrogen in the first and second plots is characterized by low availability, mobile phosphorus has medium and high availability, exchangeable potassium has high and medium availability. Doses of mineral fertilizers were determined by a conventional method, according to V.I. Filin [11].

To obtain the expected yields of vegetable crops, there were two factors in the experiment: the first one is water regime of the soil (factor A), the second one fertilizer dose (factor B).

In the first plot we studied optimal water and fertilizer regimes of the soil for cultivating table beet cultivar 'Bordo' from 2015 to 2017. A field two-factor experiment was conducted on the territory of individual entrepreneur 'Kolesnikov' in the Kuzmich village of Gorodishchensky district according to the following scheme:

1) irrigation regime - water regime of the soil was studied: irrigation was carried out along with humidity decrease to 70,80 and $90 \%$ of FMC in active soil layer. 2 variants of soil wetting depth were planned: the first $-0.3 \mathrm{~m}$ during 'planting root formation' and $0.5 \mathrm{~m}$ during 'root formation - technical ripeness' and the second $-0.5 \mathrm{~m}$;

2) mineral fertilizers: rates of mineral fertilizers were calculated by the balance method for yields of $60,70,80 \mathrm{t} / \mathrm{ha}$. In all variants according to the irrigation regime, they had the following rates: 1) $\mathrm{N}_{130} \mathrm{P}_{80} \mathrm{~K}_{20}$;2) $\mathrm{N}_{180} \mathrm{P}_{130} \mathrm{~K}_{60}$; 3) $\mathrm{N}_{230} \mathrm{P}_{180} \mathrm{~K}_{100}$.

In the second plot investigations were carried out from 2015 to 2016 to study the effect of differentiated irrigation regimes and various fertilizer rates on carrot yields. The experiments were carried out on the territory of the Kuzmich village of "Kuzmichevsky' farm in Gorodishchensky district. The experiments were based on a two-factor scheme:

The first factor - irrigation regime: $70-80-70 ; 70-90-80 ; 80-80-80 \%$ of FMC (Table 1). 
Differentiation of pre-irrigation soil moisture depending on carrot growth stages

\begin{tabular}{|c|c|c|c|}
\hline \multirow{2}{*}{$\begin{array}{l}\text { Irrigation } \\
\text { regime } \\
\text { variants }\end{array}$} & \multicolumn{3}{|c|}{ Pre-irrigation soil moisture, \% of FMC } \\
\hline & $\begin{array}{l}\text { Emergence - beginning } \\
\text { of root formation }\end{array}$ & $\begin{array}{l}\text { Beginning of root formation - } \\
\text { beginning of technical ripeness }\end{array}$ & $\begin{array}{l}\text { Beginning of technical } \\
\text { ripeness - harvesting }\end{array}$ \\
\hline 1 & 70 & 80 & 70 \\
\hline 2 & 70 & 90 & 80 \\
\hline 3 & 80 & 80 & 80 \\
\hline
\end{tabular}

The second factor - fertilizer application. The rates of mineral fertilizers were calculated by the balance method for yields of $60,70,80 \mathrm{t} / \mathrm{ha}$. In all irrigation regime variants these rates were as following: 1-st $-\mathrm{N}_{150} \mathrm{P}_{60} \mathrm{~K}_{180} ; 2-\mathrm{nd}-\mathrm{N}_{180} \mathrm{P}_{80} \mathrm{~K}_{220}$; 3-rd $\mathrm{N}_{210} \mathrm{P}_{100} \mathrm{~K}_{260}(80 \mathrm{t} / \mathrm{ga})$.

In both studies season irrigation was carried out using drip irrigation.

During carrot cultivation active soil layer was $0.5 \mathrm{~m}$. The irrigation rates were $250 \ldots 300 \mathrm{~m}^{3} / \mathrm{ha}, 208 \ldots 300 \mathrm{~m}^{3} /$ ha and $250 \mathrm{~m}^{3} /$ ha. Carrots 'Mayor F1' hybrid seeds were sown using common regional agricultural techniques.

\section{RESULTS AND DISCUSSION}

The results of three-year research on light chestnut soils of the Volga-Don interfluve have shown that the applied irrigation regimes and the application rates of mineral fertilizers along with drip irrigation make it possible to obtain expected yields of table beets and carrots at a level of $60 \ldots 80 \mathrm{t} / \mathrm{ha}$.

In our experiment, to maintain the water regimes of the soil a different number of irrigations were required. The data shown in Table 2 indicate that increase in humidity from 70 to $90 \%$ of FMC results in increase in number of irrigations and irrigation rates, and irrigation rate decreases.

The irrigation regime of table beet on average for 2015-2017

Table 2

\begin{tabular}{|c|c|c|c|}
\hline $\begin{array}{c}\text { Pre-irrigation soil } \\
\text { moisture, \% of FMC }\end{array}$ & $\begin{array}{c}\text { Watering rate, } \\
\mathrm{m}^{3} / \mathrm{ha}\end{array}$ & $\begin{array}{c}\text { Number of season } \\
\text { irrigations }\end{array}$ & Irrigation rate, $\mathrm{m}^{3} / \mathrm{ha}$ \\
\hline \multicolumn{5}{|c|}{ At a depth of soil moistening $0.5 \mathrm{~m}$} \\
\hline 70 & 360 & 9 & 3240 \\
\hline 80 & 240 & 15 & 3600 \\
\hline 90 & 120 & 32 & 3840 \\
\hline \multicolumn{5}{|c|}{ At a depth of soil moistening $0.3-0.5 \mathrm{~m}$} \\
\hline 70 & $220-360$ & $7-5$ & 3340 \\
\hline 80 & $148-240$ & $11-9$ & 3788 \\
\hline 90 & $75-120$ & $21-19$ & 3855 \\
\hline
\end{tabular}

Irrigation regime, crop yield and meteorological conditions of the growing season have a decisive influence on the amount of total water consumption. The total consumption of moisture in the experiments increased with an increase in water availability from $4,417 \mathrm{~m}^{3} /$ ha in the variant with $70 \%$ of $\mathrm{FMC}$ to $5,105 \mathrm{~m}^{3} /$ ha in the variant with $90 \%$ of FMC. The highest total water consumption of table beet was in the variant with a differentiated wetting depth and averaged 4,530...5,105 $\mathrm{m}^{3} / \mathrm{ha}$. Share of irrigation water in total water consumption of plants increased from 73.3 to $75.7 \%$, as water availability improved (Table 3 ). 
Total water consumption of table beet and its structure on average for 2015-2017

\begin{tabular}{|c|c|c|c|c|c|c|c|}
\hline \multirow{3}{*}{$\begin{array}{l}\text { Pre-irrigation } \\
\text { soil moisture, } \\
\% \text { of FMC }\end{array}$} & \multicolumn{6}{|c|}{ Water source } & \multirow{3}{*}{$\begin{array}{c}\text { Total water } \\
\text { consumption, } \\
\mathrm{m}^{3} / \mathrm{ha}\end{array}$} \\
\hline & \multicolumn{2}{|c|}{ watering } & \multicolumn{2}{|c|}{ precipitation } & \multicolumn{2}{|c|}{ soil } & \\
\hline & $\mathrm{m}^{3} / \mathrm{ha}$ & $\%$ from $\mathrm{E}$ & $\mathrm{m}^{3} / \mathrm{ha}$ & $\%$ of $E$ & $\mathrm{~m}^{3} / \mathrm{ha}$ & $\%$ of $E$ & \\
\hline \multicolumn{8}{|c|}{ At $0.5 \mathrm{~m}$ wetting depth } \\
\hline 70 & 3240 & 73.3 & 1045 & 23.7 & 132 & 3.0 & 4417 \\
\hline 80 & 3600 & 74.6 & 1045 & 21.6 & 185 & 3.8 & 4830 \\
\hline 90 & 3840 & 75.7 & 1045 & 20.6 & 190 & 3.7 & 5075 \\
\hline \multicolumn{8}{|c|}{ At $0.3-0.5 \mathrm{~m}$ wetting depth } \\
\hline 70 & 3340 & 73.7 & 1045 & 23.1 & 145 & 3.2 & 4530 \\
\hline 80 & 3788 & 75.3 & 1045 & 20.8 & 198 & 3.9 & 5031 \\
\hline 90 & 3855 & 75.5 & 1045 & 20.5 & 205 & 4.0 & 5105 \\
\hline
\end{tabular}

Yield of table beet on average for 2015-2017

\begin{tabular}{|c|c|c|c|}
\hline \multicolumn{3}{|c|}{ Factors } & \multirow[t]{2}{*}{ Yield, t/ha } \\
\hline $\begin{array}{c}\text { Fertilizer rate, } \\
\text { kg of active ingredient } \\
\text { per } 1 \text { ha }\end{array}$ & $\begin{array}{l}\text { Pre-irrigation soil moisture, } \\
\% \text { of FMC }\end{array}$ & Wetting depth, m & \\
\hline $\mathrm{N}_{130} \mathrm{P}_{80} \mathrm{~K}_{20}$ & 70 & 0.5 & 49.7 \\
\hline $\mathrm{N}_{130} \mathrm{P}_{80} \mathrm{~K}_{20}$ & 70 & $0.3-0.5$ & 54.9 \\
\hline $\mathrm{N}_{130} \mathrm{P}_{80} \mathrm{~K}_{20}$ & 80 & 0.5 & 59.7 \\
\hline $\mathrm{N}_{130} \mathrm{P}_{80} \mathrm{~K}_{20}$ & 80 & $0.3-0.5$ & 63.7 \\
\hline $\mathrm{N}_{130} \mathrm{P}_{80} \mathrm{~K}_{20}$ & 90 & 0.5 & 56.4 \\
\hline $\mathrm{N}_{130} \mathrm{P}_{80} \mathrm{~K}_{20}$ & 90 & $0.3-0.5$ & 58.9 \\
\hline $\mathrm{N}_{180} \mathrm{P}_{130} \mathrm{~K}_{60}$ & 70 & 0.5 & 59.4 \\
\hline $\mathrm{N}_{180} \mathrm{P}_{130} \mathrm{~K}_{60}$ & 70 & $0.3-0.5$ & 62.3 \\
\hline $\mathrm{N}_{180} \mathrm{P}_{130} \mathrm{~K}_{60}$ & 80 & 0.5 & 67.3 \\
\hline $\mathrm{N}_{180} \mathrm{P}_{130} \mathrm{~K}_{60}$ & 80 & $0.3-0.5$ & 78.3 \\
\hline $\mathrm{N}_{180} \mathrm{P}_{130} \mathrm{~K}_{60}$ & 90 & 0.5 & 62.7 \\
\hline $\mathrm{N}_{180} \mathrm{P}_{130} \mathrm{~K}_{60}$ & 90 & $0.3-0.5$ & 65.4 \\
\hline $\mathrm{N}_{230} \mathrm{P}_{180} \mathrm{~K}_{100}$ & 70 & 0.5 & 69.3 \\
\hline $\mathrm{N}_{230} \mathrm{P}_{180} \mathrm{~K}_{100}$ & 70 & $0.3-0.5$ & 72.0 \\
\hline $\mathrm{N}_{230} \mathrm{P}_{180} \mathrm{~K}_{100}$ & 80 & 0.5 & 76.3 \\
\hline $\mathrm{N}_{230} \mathrm{P}_{180} \mathrm{~K}_{100}$ & 80 & $0.3-0.5$ & 84.1 \\
\hline $\mathrm{N}_{230} \mathrm{P}_{180} \mathrm{~K}_{100}$ & 90 & 0.5 & 74.1 \\
\hline $\mathrm{N}_{230} \mathrm{P}_{180} \mathrm{~K}_{100}$ & 90 & $0.3-0.5$ & 78.2 \\
\hline
\end{tabular}

Our experiments showed that different irrigation regimes and fertilizer applications had a significant impact on yield and water consumption of root crops. The maximum table beet yield of $84.1 \mathrm{t} /$ ha was obtained when soil wetting depth was $0.3-0.5 \mathrm{~m}$, soil moisture was $80 \%$ of FMC and $\mathrm{N}_{230} \mathrm{P}_{180} \mathrm{~K}_{100}$ fertilizer rate (Table 4).

Depending on the variant, table beet yield increased by $8.8 \ldots 11.5 \mathrm{t} / \mathrm{ha}$ after $\mathrm{N}_{180} \mathrm{P}_{130} \mathrm{~K}_{60}$ application and by $25.6 \ldots 29.2 \mathrm{t} /$ ha after $\mathrm{N}_{230} \mathrm{P}_{180} \mathrm{~K}_{100}$ application compared to $\mathrm{N}_{130} \mathrm{P}_{80} \mathrm{~K}_{20}$ fertilizer application.

While maintaining wetting depth at the level of $0.3 \ldots 0.5 \mathrm{~m}$ and increasing soil moisture level from 70 to $90 \%$ of FMC, table beet yield varied from 54.9 to $84.1 \mathrm{t} / \mathrm{ha}$. 
In all variants of the experiment, the highest table beet yield was obtained when pre-irrigation soil moisture was $80 \%$ of FMC and fertilization rate $-\mathrm{N}_{230} \mathrm{P}_{180} \mathrm{~K}_{100}$. Decrease or increase of pre-irrigation soil moisture in active soil layer to 70 or $90 \%$ of FMC reduced yields of root crops by $10-15 \%$.

According to the data obtained, mineral fertilizers also reduce beet water consumption. The lowest coefficient was in the second variant of irrigation regimes, when soil moisture was maintained at $80 \%$ of FMC with differentiated wetting depth. We observed it in all variants of irrigation regimes and fertilizer applications. This confirms that differentiation of wetting depth of the soil according to table beet growth stages makes it possible to use irrigation water more economically at all rates of mineral fertilizers (Table 5).

Table 5

Influence of irrigation regime and fertilizer application on water consumption of table beet on average for 2015-2017

\begin{tabular}{|c|c|c|c|c|}
\hline $\begin{array}{c}\text { Fertilizer rates, } \\
\text { kg of active } \\
\text { ingredient per } 1 \text { ha }\end{array}$ & $\begin{array}{l}\text { Pre-irrigation soil } \\
\text { moisture, \% of FMC }\end{array}$ & Yield, t/ha & $\begin{array}{c}\text { Water } \\
\text { consumption, } \\
\mathrm{m}^{3} / \text { ha }\end{array}$ & $\begin{array}{c}\text { Total water } \\
\text { consumption, } \\
\mathrm{m}^{3} / \mathrm{ha}\end{array}$ \\
\hline \multicolumn{5}{|c|}{ At $0.5 \mathrm{~m}$ wetting depth } \\
\hline $\mathrm{N}_{130} \mathrm{P}_{80} \mathrm{~K}_{20}$ & 70 & 49.7 & 88.87 & 4417 \\
\hline $\mathrm{N}_{130} \mathrm{P}_{80} \mathrm{~K}_{20}$ & 80 & 59.7 & 80.90 & 4830 \\
\hline $\mathrm{N}_{130} \mathrm{P}_{80} \mathrm{~K}_{20}$ & 90 & 56.4 & 89.98 & 5075 \\
\hline $\mathrm{N}_{180} \mathrm{P}_{130} \mathrm{~K}_{60}$ & 70 & 59.4 & 74.36 & 4417 \\
\hline $\mathrm{N}_{180} \mathrm{P}_{130} \mathrm{~K}_{60}$ & 80 & 67.3 & 71.77 & 4830 \\
\hline $\mathrm{N}_{130} \mathrm{P}_{80} \mathrm{~K}_{20}$ & 90 & 62.7 & 80.94 & 5075 \\
\hline $\mathrm{N}_{230} \mathrm{P}_{180} \mathrm{~K}_{100}$ & 70 & 69.3 & 63.74 & 4417 \\
\hline $\mathrm{N}_{230} \mathrm{P}_{180} \mathrm{~K}_{100}$ & 80 & 76.3 & 63.30 & 4830 \\
\hline $\mathrm{N}_{230} \mathrm{P}_{180} \mathrm{~K}_{100}$ & 90 & 74.1 & 68.49 & 5075 \\
\hline \multicolumn{5}{|c|}{ At $0.3-0.5 \mathrm{~m}$ wetting depth } \\
\hline $\mathrm{N}_{130} \mathrm{P}_{80} \mathrm{~K}_{20}$ & 70 & 54.9 & 82.51 & 4530 \\
\hline $\mathrm{N}_{130} \mathrm{P}_{80} \mathrm{~K}_{20}$ & 80 & 63.7 & 78.98 & 5031 \\
\hline $\mathrm{N}_{130} \mathrm{P}_{80} \mathrm{~K}_{20}$ & 90 & 58.9 & 86.67 & 5105 \\
\hline $\mathrm{N}_{180} \mathrm{P}_{130} \mathrm{~K}_{60}$ & 70 & 62.3 & 72.71 & 4530 \\
\hline $\mathrm{N}_{180} \mathrm{P}_{130} \mathrm{~K}_{60}$ & 80 & 78.3 & 64.25 & 5031 \\
\hline $\mathrm{N}_{180} \mathrm{P}_{130} \mathrm{~K}_{60}$ & 90 & 65.4 & 78.06 & 5105 \\
\hline $\mathrm{N}_{230} \mathrm{P}_{180} \mathrm{~K}_{100}$ & 70 & 72.0 & 62.92 & 4530 \\
\hline $\mathrm{N}_{230} \mathrm{P}_{180} \mathrm{~K}_{100}$ & 80 & 84.1 & 59.82 & 5031 \\
\hline $\mathrm{N}_{230} \mathrm{P}_{180} \mathrm{~K}_{100}$ & 90 & 78.2 & 65.28 & 5105 \\
\hline
\end{tabular}

In the second plot, carrots were sown on May 15. During the research years, meteorological conditions had a great influence on irrigation frequency and rates. So, for example, depending on the variant, 15...20 waterings were conducted, which amounted to irrigation rate of $4,050 \ldots 4,780 \mathrm{~m}^{3} /$ ha (Table 6).

According to the data of Table 7, differentiating pre-irrigation soil moisture and different fertilizer rates had a significant impact on carrot yield and water consumption. The data obtained show that changes in carrot productivity under drip irrigation correlate with changes in total water consumption and water consumption coefficient. In addition, carrots are very responsive to mineral fertilizer application. The maximum carrot yield of $81.6 \mathrm{t} /$ ha can be obtained by maintaining constant soil moisture at the level of $80-80-80 \%$ of FMC and applying fertilizers at the following rate $-\mathrm{N}_{210} \mathrm{P}_{100} \mathrm{~K}_{260}$. 
Table 6

Carrot irrigation regime on average for 2015-2017

\begin{tabular}{|c|c|c|c|c|c|}
\hline \multirow[t]{2}{*}{ Var. } & \multicolumn{3}{|c|}{ Pre-irrigation soil moisture, $\%$ of FMC / Irrigation rate, $\mathrm{m}^{3} /$ ha } & \multirow{2}{*}{$\begin{array}{l}\text { Number of } \\
\text { waterings }\end{array}$} & \multirow{2}{*}{$\begin{array}{l}\text { Irrigation } \\
\text { rate, } \\
\mathrm{m}^{3} / \mathrm{ha}\end{array}$} \\
\hline & $\begin{array}{l}\text { Emergence - } \\
\text { beginning of } \\
\text { root formation }\end{array}$ & $\begin{array}{l}\text { Beginning of root } \\
\text { formation - beginning } \\
\text { of technical ripeness }\end{array}$ & $\begin{array}{l}\text { Beginning of technical } \\
\text { ripeness - harvesting }\end{array}$ & & \\
\hline 1 & $\frac{70}{300}$ & $\frac{80}{250}$ & $\frac{70}{300}$ & 15 & 4050 \\
\hline 2 & $\frac{70}{300}$ & $\frac{90}{208}$ & $\frac{80}{250}$ & 20 & 4780 \\
\hline 3 & $\frac{80}{250}$ & $\frac{80}{250}$ & $\frac{80}{250}$ & 18 & 4500 \\
\hline
\end{tabular}

Table 7

Influence of irrigation regime and fertilizing on carrot yields and water consumption on average for 2015-2017

\begin{tabular}{|c|c|c|c|c|c|}
\hline \multirow{2}{*}{$\begin{array}{c}\text { Yield } \\
\text { (actual), } \\
\text { t/ha }\end{array}$} & $\begin{array}{c}\text { Pre-irrigation } \\
\text { soil moisture, } \\
\% \text { of FMC }\end{array}$ & \multicolumn{2}{|c|}{$\begin{array}{c}\text { Mineral fertilizer rates } \\
\text { for the expected yields }\end{array}$} & \multirow{2}{*}{$\begin{array}{c}\text { Coefficient } \\
\text { of water } \\
\text { consumption, } \\
\mathrm{m}^{3} / \mathrm{ha}\end{array}$} & $\begin{array}{c}\text { Total water } \\
\text { consumption, } \\
\mathrm{m}^{3} / \mathrm{ha}\end{array}$ \\
\cline { 3 - 5 } & $\mathrm{t} / \mathrm{ha}$ & $\begin{array}{c}\text { kg of active } \\
\text { ingredient per } 1 \mathrm{ha}\end{array}$ & & \\
\hline 57.9 & $70-80-70$ & 60 & $\mathrm{~N}_{150} \mathrm{P}_{60} \mathrm{~K}_{180}$ & 98.07 & 5678 \\
\hline 62.8 & $70-90-80$ & 70 & $\mathrm{~N}_{180} \mathrm{P}_{80} \mathrm{~K}_{220}$ & 92.05 & 5781 \\
\hline 71.5 & $80-80-80$ & 80 & $\mathrm{~N}_{210} \mathrm{P}_{100} \mathrm{~K}_{20}$ & 82.38 & 5890 \\
\hline 66.3 & $70-80-70$ & 60 & $\mathrm{~N}_{150} \mathrm{P}_{60} \mathrm{~K}_{180}$ & 85.64 & 5678 \\
\hline 72.0 & $70-90-80$ & 70 & $\mathrm{~N}_{180} \mathrm{P}_{80} \mathrm{~K}_{220}$ & 80.29 & 5781 \\
\hline 73.6 & $80-80-80$ & 80 & $\mathrm{~N}_{210} \mathrm{P}_{100} \mathrm{~K}_{260}$ & 80.03 & 5890 \\
\hline 68.2 & $70-80-70$ & 60 & $\mathrm{~N}_{150} \mathrm{P}_{60} \mathrm{~K}_{180}$ & 83.26 & 5678 \\
\hline 72.7 & $70-90-80$ & 70 & $\mathrm{~N}_{180} \mathrm{P}_{80} \mathrm{~K}_{220}$ & 79.52 & 5781 \\
\hline 81.6 & $80-80-80$ & 80 & $\mathrm{~N}_{210} \mathrm{P}_{100} \mathrm{~K}_{260}$ & 72.18 & 5890 \\
\hline
\end{tabular}

The irrigation water was most effectively used at soil moisture levels of $80-80$ $80 \%$ of FMC, since there was the lowest water consumption and averaged $72.18 \mathrm{~m}^{3} / \mathrm{ha}$ over research years.

Carrot yield $60 \mathrm{t} / \mathrm{ha}$ is achieved in the variant with pre-irrigation soil moisture of $70-80-70 \%$ of FMC in combination with fertilizer application $\mathrm{N}_{150} \mathrm{P}_{60} \mathrm{~K}_{180}$. So, irrigation rate was $4,050 \mathrm{~m}^{3} / \mathrm{ha}$, and total water consumption was $5,678 \mathrm{~m}^{3} / \mathrm{ha}$.

For carrot yields of $70 \mathrm{t} / \mathrm{ha}$ irrigation rate increased to $4,780 \mathrm{~m}^{3} / \mathrm{ha}$, and total water consumption increased to $5,781 \mathrm{~m}^{3} /$ ha. The maximum carrot yield $81.6 \mathrm{t} / \mathrm{ha}$ was obtained when soil moisture was $80-80-80 \%$ of FMC and fertilizer rate was increased to $\mathrm{N}_{210} \mathrm{P}_{100} \mathrm{~K}_{260}$.

Thus, our studies have shown that table beets and carrots are very responsive to the optimal combination of irrigation and fertilizer parameters. In general, application of mineral fertilizers has a significant effect on productivity and water consumption coefficient of the root crops in all irrigation regime variants.

\section{CONCLUSIONS}

Based on the data obtained, the following conclusions can be drawn.

When cultivating table beet under conditions of the Volga-Don interfluve, the optimal variant is a differentiated variant, with a variable wetting depth of soil $(0.3 \ldots 0.5 \mathrm{~m})$. 
The maximum table beet yield in this variant was obtained in the plot with soil moisture of $80 \%$ of FMC, and, depending on the variant, it was $63.7 \ldots 84.1 \mathrm{t}$ ha, which is $10 \ldots 20 \%$ higher in comparison with other variants.

The greatest carrot yield (81.6 t/ha) was achieved in the variant with pre-irrigated soil moisture $80-80-80 \%$ of FMC combined with mineral fertilizer application $\mathrm{N}_{210} \mathrm{P}_{100} \mathrm{~K}_{260}$.

(C) A.D. Akhmedov, E.E. Dzhamaletdinova, A.E. Zasimov, 2018.

\section{REFERENCES}

[1] Akhmedov AD, Temerev AA, Galiullina EY. Ecological aspects of drip irrigation. Problemy i perspektivy innovatsionnog orazvitiya mirovogo sel'skogo khozyaistva: materialy mezhdunarodnoi nauchno-prakticheskoi konferentsii Saratovskogo GAU. Saratov; 2010. P. 156-158. (In Russ).

[2] Akhmedov AD, Zasimov AE. Irrigation regime of beets in conditions of the Volga-Don interfluve. Strategicheskie orientiry innovatsionnogo razvitiya APK v sovremennykh usloviyakh: materialy mezhdunarodnoi nauchno-prakticheskoi konferentsii. Volgograd: FGBOU VO Volgogradskii GAU Publ.; 2016;3. p. 106-110. (In Russ).

[3] Borodychev VV, Martynova AA. Irrigation regime and mineral nutrition of carrots. Melioratsiya $i$ vodnoe khozyaistvo. 2011;(1):39-41. (In Russ).

[4] Borodychev VV, Martynova AA. Management of potential carrot productivity. Izvestiya Nizhnevolzhskogo agrouniversitetskogo kompleksa: nauka $i$ vysshee professional'noe obrazovanie. 2011;21(1):17-23. (In Russ).

[5] Dospekhov BA. Planirovanie polevogo opyta i statisticheskaya obrabotka ego dannykh [Planning of field experiment and statistical processing of its data]. Moscow: Kolos Publ.; 1972. 207 p. (In Russ).

[6] Filin VI. Spravochnaya kniga po rastenievodstvu s osnovami pro-grammirovaniya urozhaya [A reference book on plant growing with basics of harvest programming]. Volgograd: VGSKhA Publ.; 1994. 274 p. (In Russ)

[7] Pleshakov VN. Metodika polevogo opyta v usloviyakh orosheniya [Methodology of field experiment under irrigation]. Volgograd: VNIIOZ Publ.; 1983. 148 p. (In Russ).

[8] Dubenok HH, Borodychev VV, Martynova AA. Mineral nutrition is an important resource for increasing carrot productivity under drip irrigation. Dostizheniya nauki i tekhniki APK. 2010;(7):24-27. (In Russ). House "Education and Science" s.r.o.; 2014. p. 28-31. (In Russ).

[9] Khodyakov EA, Osinkin VV, Kovalenko IA. Optimization of irrigation regime for growing table beet and zucchini under drip irrigation in the Lower Volga region. Aplikovane vedecke novinky-2014. Materialy X mezinarodni vedecko-prakticka conference. Dil. 16 Zemdelstvi. zverolekarstvi. Praha: Publishing.

[10] Kuznetsova NV, Stepanova NE. Photosynthetic activity of table beet crops on irrigated light chestnut lands of the Lower Volga Region. Izvestiya Nizhnevolzhskogo agrouniversitetskogo kompleksa: nauka i vysshee professional'noe obrazovanie. 2011;(1):36-42. (In Russ).

[11] Nikitenko GF, editor. Opytnoe delo v polevodstve [Experimentation activity in field husbandry]. Moscow: Rossel'khozizdat Publ.; 1982. 190 p. (In Russ).

\section{Author's personal data:}

Askar Jangir oglu Ahmedov — professor, Doctor of Engineering Science, Volgograd State Agricultural University; e-mail: askar-5@mail.ru

Djamaletdinova Elena Eurikovna — PhD. student, Volgograd State Agricultural University; e-mail: lena.adi@mail.ru 
Anton Evgenievich Zasimov — Ph.D. student, Volgograd State Agricultural University; e-mail: zasimov.anton@gmail.com

\title{
For citation:
}

Akhmedov AD, Dzhamaletdinova EE, Zasimov AE. Water-saving irrigation regimes for vegetable crop production under conditions of Volga-Don interfluve. RUDN Journal of Agronomy and Animal Industries, 2018, 13 (3), 185-193. doi: 10.22363/2312-797X-2018-13-3-185-193.

\section{ВОДОСБЕРЕГАЮЩИЕ РЕЖИМЫ ОРОШЕНИЯ ОВОЩНЫХ КУЛЬТУР В УСЛОВИЯХ ВОЛГО-ДОНСКОГО МЕЖДУРЕЧЬЯ}

\author{
А.Д. Ахмедов, Е.Э. Джамалетдинова, А.Е. Засимов \\ ФГБОУ ВО Волгоградский государственный аграрный университет \\ пр. Университетский, 26, Волгоград, 400002, Российская Федераџия
}

Рассмотрены режимы орошения и нормы внесения минеральных удобрений для получения запланированной урожайности овощных культур в условиях светло-каштановых почв Волго-Донского междуречья. Установлено, что предлагаемые в нашем полевом исследовании режимы орошения и нормы минеральных удобрений при выращивании столовой свеклы и моркови позволяют получать урожайность в пределах $60 \ldots 80$ т/га. Так, например, максимальная урожайность столовой свеклы 84,1 т/га получена на варианте с влажностью $80 \%$ НВ в сочетании с внесением удобрений нормой $\mathrm{N}_{230} \mathrm{P}_{180} \mathrm{~K}_{100}$ при переменной глубины увлажнения почвы $(0,3 \ldots 0,5$ м). Изменение дозы удобрений от $\mathrm{N}_{130} \mathrm{P}_{80} \mathrm{~K}_{20}$, до $\mathrm{N}_{230} \mathrm{P}_{180} \mathrm{~K}_{100}$ способствовало повышению урожая в пределах 63,784,1 т/га, что на $10 . .20 \%$ выше по сравнению с другими вариантами опыта. При возделывании моркови изменение влажности почвы от 70-80-70 до 80-80-80\% НВ в сочетании с внесением дозы удобрений от $\mathrm{N}_{150} \mathrm{P}_{70} \mathrm{~K}_{180}$ до $\mathrm{N}_{210} \mathrm{P}_{100} \mathrm{~K}_{260}$ способствовало повышению урожайности корнеплодов в среднем с 57,9 до 81,6 т/га. Наиболее высокие показатели урожайности 81,6 т/га получены при поддержании предполивного порога влажности $80-80-80 \%$ НВ при норме минерального питания $\mathrm{N}_{210} \mathrm{P}_{100} \mathrm{~K}_{260}$. В целом, на светло-каштановых почвах выращивание столовой свеклы и моркови с применением капельного полива и внесения удобрений является наиболее эффективным.

Ключевые слова: капельное орошение овощных культур, режим орошения овощных культур, свекла столовая, морковь, урожайность овощных культур, удобрение овощных культур, коэффициент водопотребления столовой свеклы и моркови, суммарное водопотребление столовой свеклы и моркови, предполивная влажность почвы

\section{БИБЛИОГРАФИЧЕСКИЙ СПИСОК}

[1] Ахмедов А.Д. Экологические аспекты капельного орошения [Текст] / А.Д. Ахмедов, А.А. Темерев, Е.Ю. Галиуллина // Проблемы и перспективы инновационного развития мирового сельского хозяйства: материалы междунар. науч.-практ. конф. Саратовского ГАУ. Саратов, 2010. С. 156-158.

[2] Ахмедов А.Д. Поливной режим свеклы в условиях Волго-Донского междуречья [Текст]/ А.Д. Ахмедов, А.Е. Засимов // Стратегические ориентиры инновационного развития АПК в современных условиях: материалы междунар. науч.-практ. конф. Т. 3. Волгоград: ФГБОУ ВО Волгоградский ГАУ, 2016. С.106-110. 
[3] Бородычев В.В. Режим орошения и минеральное питание моркови [Текст] / В.В. Бородычев, А.А. Мартынова // Мелиорация и водное хозяйство. 2011. № 1. С. $39-41$.

[4] Бородычев B.B. Управление реализацией потенциальной продуктивности моркови [Текст] / В.В. Бородычев, А.А. Мартынова // Известия Нижневолжского агроуниверситетского комплекса: наука и высшее профессиональное образование. 2011. № 1 (21). С. 17-23.

[5] Дубенок Н.Н. Минеральное питание - важный ресурс повышения продуктивности моркови при капельном орошении [Текст] / Н.Н. Дубенок, В.В. Бородычев, А.А. Мартынова // Достижения науки и техники АПК. 2010. № 7. С. 24-26.

[6] Филин В.И. Справочная книга по растениеводству с основами программирования урожая [Текст] / В.И. Филин. ВГСХА. Волгоград, 1994. 274 с.

[7] Плешаков В.Н. Методика полевого опыта в условиях орошения [Текст] / В.Н. Плешаков. Волгоград: ВНИИОЗ, 1983. 148 с.

[8] Доспехов Б.А. Планирование полевого опыта и статистическая обработка его данных [Текст] / Б.А. Доспехов. М.: Колос, 1972. 207 с.

[9] Ходяков Е.А. Оптимизация режима орошения для выращивания столовой свеклы и кабачков при капельном поливе в Нижнем Поволжье [Текст] / Е.А. Ходяков, В.В. Осинкин, И.А. Коваленко // Aplikovanevedeckenovinky-2014. Materialy X mezinarodni vedeckoprakticka conference. Dil. 16 Zemdelstvi. zverolekarstvi. Praha: PublishingHouse "Education and Science" s.r.o, 2014. p. 28-31.

[10] Кузнецова Н.В. Фотосинтетическая деятельность посевов столовой свеклы на орошаемых светло-каштановых землях Нижнего Поволжья [Текст] / Н.В. Кузнецова, Н.Е. Степанова // Известия Нижневолжского агроуниверситетского комплекса: наука и высшее профессиональное образование. 2011. № 1. С. 36-42.

[11] Никитенко Г.Ф. и др. Опытное дело в полеводстве [Текст] / Г.Ф. Никитенко. М.: Россельхозиздат, 1982.

\section{Для цитирования:}

Ахмедов А.Д., Джамалетдинова Е.Э., Засимов А.Е. Водосберегающие режимы орошения овощных культур в условиях Волго-донского междуречья // Вестник Российского университета дружбы народов. Серия: Агрономия и животноводство. 2018. Т. 13. № 3. С. 185-193. doi: 10.22363/2312-797Х-2018-13-3-185-193. 